\title{
Evaluation of insecticidal activity of three plant extracts against adult Tribolium castaneum (Herbst)
}

\author{
Ruhul Amin', \\ Ripon Mondol', \\ Faridur Rahman ${ }^{2}$, \\ Jahangir Alam ${ }^{1}$, \\ Rowshanul Habib ${ }^{1}$, \\ Tofazzal Hossain ${ }^{1 *}$ \\ ${ }^{1}$ Department of Biochemistry \\ and Molecular Biology, \\ Rajshahi University, \\ Rajshahi-6205, Bangladesh \\ ${ }^{2}$ Department of Molecular Biology \\ and Functional Genomics, \\ Stockholm University, \\ SE-10691 Stockholm, Sweden
}

\begin{abstract}
Screening of plant extracts from wild species of plants for insecticidal properties could lead to the discovery of new agents for pest control. Keeping this in view, the insecticidal activity of three plant extracts Helencha (Enhydra fluctuans Lour), Ghetu (Clerodendrum viscosum Vent) and Kalomegh (Andrographis peniculata Wall) were tested against stored grain pest Tribolium castaneum (Herbst). In residual film bioassay, five doses, i. e. 0.629, 0.472, $0.315,0.157$ and $0.078 \mathrm{mg} / \mathrm{cm}^{2}$ of methanol extract of leaves of each plant species were applied on adult Tribolium castaneum. After 36 hours, the lowest $\mathrm{LD}_{50}$ for the methanol extract of leaves of Enhydra fluctuans, Clerodendrum viscosum and Andrographis peniculata were found to be $0.351,0.622$ and $0.977 \mathrm{mg} / \mathrm{cm}^{2}$, respectively. According to the intensity of activity, the toxicity was found in the order of Enhydra fluctuans > Clerodendrum viscosum $>$ Andrographis peniculata. The overall results suggest that these three plants have potential insecticidal effect which might be used in pest control.
\end{abstract}

Key words: Andrographis peniculata, Clerodendrum viscosum, Enhydra fluctuans, insecticidal activity, Tribolium castaneum

\section{INTRODUCTION}

Pest control is a major concern in agriculture and horticulture growers for underdeveloped

\footnotetext{
*Corresponding author. E-mail: thossainbd@yahoo.com
}

agro-based countries (Ahmed et al., 2009). The red flour beetle, Tribolium castaneum (Herbst), is a common and the most vicious pest among important stored-product insects and pests all over the world (Pranoto et al., 1991). Scientifically it has been reported that the germ part 
(embryo portion) of the grain is destroyed by red flour beetle Tribolium castaneum. Their presence in grain type stored foods directly affects both the quantity and quality of the commodity (Sagheer et al., 2011; Okonkwo, Okoye, 1996; (Rahman et al., 2011). In Bangladesh, it is generally found coupled with stored grain of different cereals. In essence, the cracked grain or breakfast food or meal, rice, dried fruit, bleached and unbleached white flour, cornmeal, barley, flour, oatmeal, etc. are the main targets of them (Via, 1999; Alam et al., 2009). However, an individual uses various synthetic insecticides and fumigants to control this pest, which have serious effects on environment, increasing pest resistance to pesticides, pest revival, and lethal effects on non-target organisms as well as direct toxicity to users (Robinson, 2005; Islam et al., 2011; Jembere et al., 1995). Due to the problems associated with the indiscriminate use of synthetic insecticides, like insect resistance and impact on nontarget organisms, many scientists have given an extra impulse to search alternative ways to control this pest (Dyte, Blackman, 1972). Botanical insecticides are considered as an alternative to the synthetic chemicals for being biodegradable, pest specific, non-hazardous to human health and environment and leaving no toxic residue in nature (Farhana et al., 2006; Periera, Wohlgemuth, 1982). However, few works have been done in Bangladesh to determine the efficacy of our locally available plant materials against Tribolium castaneum. In this study, we have chosen to investigate the insecticidal activity of three plants, namely Enhydra fluctuans Lour (traditional name: Helencha; Family: Compositae), Clerodendrum viscosum Vent (traditional name: Ghetu; Family: Verbenaceae) and Andrographis peniculata Wall (traditional name: Kalomegh; Family: Acanthaceae) against Tribolium castaneum (Herbst).

\section{MATERIALS AND METHODS}

\section{Plant materials}

Leaves of Enhydra fluctuans, Clerodendrum viscosum and Andrographis peniculata were collected in October, 2011 from Rajshahi district of Bangladesh and the plant material was taxonomically identified by Prof. A. T. M. Naderuz- zaman, Department of Botany, University of Rajshahi. Voucher specimens were deposited under the accession numbers DACB-21401 for Enhydra fluctuans, DACB-20710 for Clerodendrum viscosum and DACB-18612 for Andrographis peniculata at the Bangladesh National Herbarium.

\section{Extraction}

The collected leaves of each plant were cleaned and shade-dried. The dried leaves were pulverized into a coarse powder by a grinding machine (FFC-15, China) and then extracted with methanol at room temperature. Each extract was filtered through filter papers and the filtrate was evaporated under reduced pressure at $40{ }^{\circ} \mathrm{C}$ using a rotary evaporator to have $0.87,2.2$ and $2.4 \mathrm{~g}$ methanol extract of leaves of Enhydra fluctuans, Clerodendrum viscosum and Andrographis peniculata, respectively.

\section{Insects}

Red flour beetles Tribolium castaneum were used to examine the pesticidal activity of leaves of Enhydra fluctuans, Clerodendrum viscosum and Andrographis peniculata. Adult and larval stages of insect were taken from the Department of Zoology, University of Rajshahi, where pest culture was maintained for last 10 years in an incubator at $30 \pm 1{ }^{\circ} \mathrm{C}, 65 \%$ relative humidity and 12:12 h dark / light photoperiod which had been reported an optimum for rapid growth (Saleem, Shakoori, 1986). Insects were reared on a diet mixture of whole meal flour with Bakers yeast (19:1) (Mondal, Akhtar, 1994). After every three days the medium was replaced by a fresh one to avoid conditioning by the larvae (Mondal, 1983).

\section{Residual film method of toxicity}

Residual film method as described by Busvine (Busvine, 1971) was used. A preliminary screening of different doses was performed on several instars of larvae and adults to obtain $0 \%$ to $100 \%$ mortalities. Then 200, 150, 100, 50 and $25 \mathrm{mg}$ of methanol extract of each plant were dissolved separately in $5 \mathrm{ml}$ of corresponding solvent to get concentrations of $40,30,20,10$ and $5 \mathrm{mg} / \mathrm{ml}$, respectively, which were used as stock solutions. $1 \mathrm{ml}$ of various concentrations for each sample 
was applied on petri dishes (9 $\mathrm{cm}$ diameter) in such a way that it made a uniform film over the petri dishes. For solvent evaporation, the petri dishes were air dried leaving the extract on it. The actual extract present in $1 \mathrm{ml}$ mixture was calculated and the dose per square centimeter was determined by dividing the value present in one $\mathrm{ml}$ with the area of the petri dish. Doses thus calculated were $0.629,0.472,0.315,0.157$ and $0.078 \mathrm{mg} / \mathrm{cm}^{2}$. After drying, 10 beetles were released in each petri dish with three replications. A control batch was also maintained with the same number of insects after preparing the petri dish by applying and evaporating the solvent only. The treated beetles were placed in an incubator at the same temperature as reared in stock cultures and the mortality of the beetles was counted after 24-hour post-exposure (Islam et al., 2004).

\section{Statistical analysis}

The mortality data were subjected to Probit analysis for the determination of $\mathrm{LD}_{50}$ values using the computer software SPSS of 14 version. Results with $\mathrm{P}<0.05$ were considered to be statistically significant.

\section{RESULTS AND DISCUSSION}

In the present investigation the toxicity of leaves of Andrographis peniculata, Clerodendrum viscosum, Enhydra fluctuans was tested against adults of Tribolium castaneum. The mortality (\%) was recorded and statistical data regarding $\mathrm{LD}_{50}, 95 \%$ confidence limit and chi-square values were calculated and presented in the Table. After 36-hour exposure, the lowest $\mathrm{LD}_{50}$ values of methanol extract of leaves of Enhydra fluctuans, Andrographis peniculata and Clerodendrum viscosum against adult Tribolium castaneum were found to be 0.351 , 0.622 and $0.977 \mathrm{mg} / \mathrm{cm}^{2}$, respectively. No mortality was observed in control. The overall results of this study indicated that the mortality caused by each sample was increased with the increasing of exposure time. This finding is quite similar to the previous research (Osman et al., 2011) in which the exposure time played an important role in influencing susceptibility.

Developing countries in Asia and Africa, including Bangladesh, have a long history to protect stored grains with locally available herbal substances, where the application of plant materials is simple and aqueous extracts in several

Table. Insecticidal activity of leaves of Enhydra fluctuans, Clerodendrum viscosum and Andrographis peniculata against adult Tribolium castaneum (Herbst)

\begin{tabular}{|c|c|c|c|c|c|}
\hline \multirow[t]{2}{*}{ Sample } & \multirow{2}{*}{$\begin{array}{l}\text { Exposure } \\
\text { time }\end{array}$} & \multirow{2}{*}{$\begin{array}{c}\mathrm{LD}_{50} \\
\left(\mathrm{mg} / \mathrm{cm}^{2}\right)\end{array}$} & \multicolumn{2}{|c|}{$\begin{array}{l}\text { 95\% Confidence } \\
\text { Limits }\end{array}$} & \multirow{2}{*}{$\begin{array}{c}\text { Chi-square, } \\
\chi^{2} \\
\text { (Degree of } \\
\text { freedom) }\end{array}$} \\
\hline & & & Lower & Upper & \\
\hline \multirow{4}{*}{$\begin{array}{l}\text { Methanol extract } \\
\text { of Enhydra fluctuans }\end{array}$} & $30 \min$ & 9.354 & 0.721 & 716.5 & $0.580(2)$ \\
\hline & $12 \mathrm{~h}$ & 2.211 & 1.129 & 4.327 & $0.021(3)$ \\
\hline & $24 \mathrm{~h}$ & 0.876 & 0.614 & 1.251 & $0.148(3)$ \\
\hline & $36 \mathrm{~h}$ & $0.351^{*}$ & 0.274 & 0.451 & $9.366(3)$ \\
\hline \multirow{4}{*}{$\begin{array}{l}\text { Methanol extract } \\
\text { of Clerodendrum viscosum }\end{array}$} & $30 \mathrm{~min}$ & 11.302 & 0.152 & 8.381 & $0.901(2)$ \\
\hline & $12 \mathrm{~h}$ & 1.994 & 1.674 & 2.376 & $0.220(3)$ \\
\hline & $24 \mathrm{~h}$ & $1.197^{\star}$ & 0.934 & 1.535 & $8.930(3)$ \\
\hline & $36 \mathrm{~h}$ & $0.622^{*}$ & 0.306 & 1.264 & $8.701(3)$ \\
\hline \multirow{4}{*}{$\begin{array}{c}\text { Methanol extract } \\
\text { of Andrographis peniculata }\end{array}$} & $30 \mathrm{~min}$ & 9.869 & 0.283 & 520.1 & $0.827(1)$ \\
\hline & $12 \mathrm{~h}$ & 2.744 & 1.948 & 3.864 & $3.823(3)$ \\
\hline & $24 \mathrm{~h}$ & 1.892 & 1.517 & 2.360 & $3.288(3)$ \\
\hline & $36 \mathrm{~h}$ & $0.977^{\star}$ & 0.791 & 1.205 & $3.931(1)$ \\
\hline
\end{tabular}

\# Values were based on four doses with 30 insects each.

\# Control groups showed no mortality.

* Significant at $\mathrm{P}<0.05$ level 
cases proved to be highly effective against stored product insects (Mondal, 1994). Therefore, the use of plant products (crude extracts, oil, powders, etc.) as insecticides in stored product protection might benefit the farmers by a reduction of protection costs, insecticide resistance development and environmental impact in terms of insecticidal hazard. Our results have shown that Enhydra fluctuans possesses high insecticidal activity against adult Tribolium castaneum as compared with other two plants. Results of this study point out that the three plants of this study might be useful as potent insect control agents. Our next approach will be targeted to concentrate efforts in a few more promising extracts to fractionate them and isolate possible active compounds.

Received 30 May 2012

Accepted 14 August 2012

\section{References}

1. Ahmed BI, Onu I, Mudi L. Field bioefficacy of plant extracts for the control of post flowering insect pests of cowpea (Vigna unguiculata L. Walp) in Nigeria. J Biopest 2009; 2: 37-43.

2. Alam MA, Habib MR, Nikkon F, Khalequzzaman M, Karim MR. Insecticidal Activity of Root Bark of Calotropis gigantean L. Against Tribolium castaneum (Herbst). World J Zool 2009; 4: 90-5.

3. Busvine JR. A critical review of the techniques for testing insecticides. Commonwealth Agricultural Buereux, London, 1971: 345.

4. Dyte CE, Blackman DG. Laboratory evaluation of organophosphorus insecticides against susceptible and malathion-resistant strains of Tribolium castaneum (Herbst) (Coleoptera, Tenebrionidae). J Stored Prod Res 1972; 8: 103-9.

5. Farhana K, Islam H, Emran EH, Islam N. Toxicity and repellant activity of three spice materials on Tribolium castaneum (Herbst) adult. J Bio-sci 2006; 14: 127-30.

6. Islam H, Farhana K, Islam N. Screening of spices for biological activity against Tribolium castaneum (Herbst) adualts. University Journal of Zoology, Rajshahi University 2004; 23: 65-8.
7. Islam MS, Zahan R, Nahar L, Alam MB, Naznin GC, Sarkar MA, Mosaddik MA, Haque ME. Antibacterial, insecticidal and in vivo cytotoxicity activities of Salix Tetrasperma. IJPSR 2011; 2: 2103-8.

8. Jembere BD, Obeng-Ofori A, Hassanali, Nyamasyo GNN. Products derived from the leaves of Ocimum kilimand scharicum (labiatae) as postharvest grain protestants against the infestation of three major stored product insect pests. Bull Entomol Res 1995; 85: 361-7.

9. Mondal K, Akhtar N. Toxicity of caffeine and caster oil to Tribolium castaneum (Herbst) adults and larvae. Pak J Zool 1994; 24: 283-6.

10. Mondal K. Flour beetles Tribolium spp. (Coleoptera: Tenebrionidae) as pests and their control. Agr Zool Rev 1994; 6: 95-119.

11. Mondal K. Response of Tribolium castaneum (Herbst) larvae to the different components of conditioned medium. Tribol Inform Bull 1983; 23: $110-1$.

12. Okonkwo EU, Okoye WI. The efficacy of four seed powders and the essential oils as protectants of cowpea and maize grains against infestation by Callosobruchus maculatus (Fabricus) (Coleoptera: Bruchidae) and Sitophilus zeamais (Motschulsky) (Coleoptera: Curculionidae) in Nigeria. Int J Pest Manage 1996; 42:143-6.

13. Osman MA, Aziz MA, Habib MR, Karim MR. Pesticidal Evaluation of Manilkara zapota (L.) against Tribolium castaneum (Herbst). Agr Cons Sci 2011; 76: 143-6.

14. Periera J, Wohlgemuth R. Neem (Azadirachta indica A. Juss.) of West African origin as a protectant of stored maize. Z Ang Ent 1982; 24: 208-14.

15. Pranoto RI, Sim MS, Howie AME, Ho SH. Grain Storage Pand control practices in Singapore. In: Current Trends in Integrated Pest Management for Grain Storage in the ASEAN Region. Frio AS. ASEAN Grain Postharvest Programme (eds.) Thailand 1991: 67-80.

16. Rahman MF, Karim MR, Alam MJ, Islam MF, Habib MR, Uddin MB, Hossain MT. Insecticidal effect of oyster mushroom (Pleurotus ostreatus) against Tribolium castaneum (Herbst), Nat Products-An Ind J 2011; 7: 187-90.

17. Robinson WH. Urban Insects and Arachnids. A Handbook of Urban Entomology. Cambridge University Press, Cambridge, UK. 2005. 
18. Sagheer M, Mansoor-ul-Hasan, Latif MA, Iqbal J. Evaluation of some indigenous medicinal plants as a source of toxicant, repellent and growth inhibitors against Tribolium castaneum (Coleoptera: Tenebrionidae). Pak J Entomol 2011; 33: 87-91.

19. Saleem MA, Shakoori AR. The effect of seven different relative humidities on survival and body weight loss of starved Tribolium castaneum adults. Pak J Zool 1986; 18: 95-402.

20. Via S. Cannibalism facilitates the use of a novel environment in the flour beetle, Tribolium castaneum. Heredity 1999; 82: 267-75.
Ruhul Amin, Ripon Mondol, Faridur Rahman, Jahangir Alam, Rowshanul Habib, Tofazzal Hossain

TRIJŲ AUGALŲ EKSTRAKTŲ INSEKTICIDINIO AKTYVUMO PRIEŠ TRIBOLIUM CASTANEUM (HERBST) SUAUGE்LIUS İVERTINIMAS

\section{Santrauka}

Laukinių augalų rūšių ekstraktų insekticidinių savybių patikrinimas gali inicijuoti naujų kenkèjų kontrolès priemonių atradimą. Atsižvelgiant ị tai buvo patikrintas trijų augalų (Enhydra fluctuans Lour, Clerodendrum viscosum Vent, Andrographis peniculata Wall) ekstraktų insekticidinis aktyvumas prieš grūdų saugyklų kenkèją Tribolium castaneum (Herbst). Suaugę vabalai buvo veikiami kiekvieno augalo lapų metanoliniu ekstraktu (penkiomis skirtingomis dozėmis: 0,629, 0,472, 0,315, 0,157 ir 0,078 $\mathrm{mg} / \mathrm{cm}^{2}$ ). Po 36 valandų nustatyta žemiausia Enhydra fluctuans, Clerodendrum viscosum ir Andrographis peniculata lapų metanolinių ekstraktų dozė atitinkamai buvo 0,351, 0,622 ir $0,977 \mathrm{mg} / \mathrm{cm}^{2}$. Pagal insekticidinio aktyvumo intensyvumą augalai išsidèsto šia tvarka: Enhydra fluctuans, Clerodendrum viscosum, Andrographis peniculata. Gauti rezultatai rodo, kad visi trys augalai pasižymi potencialiu insekticidiniu efektyvumu ir gali būti naudojami kenkèjų kontrolei.

Raktažodžiai: Andrographis peniculata, Clerodendrum viscosum, Enhydra fluctuans, insekticidinis aktyvumas, Tribolium castaneum 